\title{
2
}

\section{US 116th Congress sets new record for members with STEM backgrounds}

$T^{i}$ he 116th United States Congress has the greatest number of members with STEM (science, technology, engineering, and mathematics) and medical backgrounds ever elected. Convened in January 2019, the 116th Congress also saw gains in diversity across the spectrum.

The 2018 midterm elections were record-setting in several ways - the diversity of the candidate pool, the number of candidates running, the relatively high voter turnout (highest turnout in a midterm US election since 1914), the spike in young (under 30 ) voters, and the highest level of fundraising for congressional elections.

So what galvanized so many new and diverse candidates to run? What drove more people, especially younger people, to vote? What incentivized donors, specifically individuals, to fund these candidates? And what brought scientists out in record numbers to join in the political discourse and run for office? "It comes down to representation," says Alan Hurd, executive advisor at Los Alamos National Laboratory and a former Franklin Fellow who served as a science and technology advisor to the US Secretary of State. Hurd, a materials researcher, says that for many, especially those within the science community, the motivation is "defensive," and Ilke Arslan, group leader for electron and x-ray microscopy at Argonne National Laboratory, agrees saying that she believes the motivation came from "constant feelings of not being heard as a community."

"Many within the science community feel there has been a clear trend of disregard for science in Washington, most significantly over the last two years," Arslan says. And scientists often point to topics like the president's budget requests (that proposed drastic cuts to most science budgets), the fact that it took 18 months before a science advisor was nominated, and the debate over climate change, as

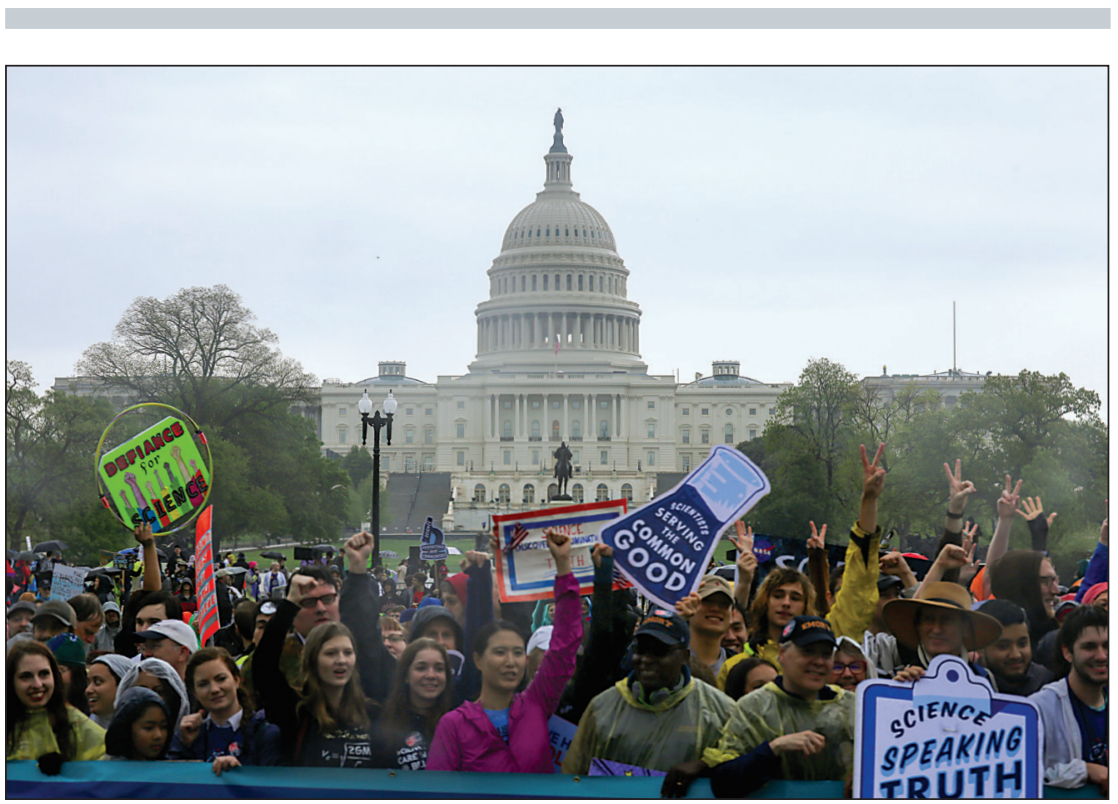

The March for Science held in Washington, DC, on April 27, 2017, focused the public's attention on the importance of science in daily life. Credit: Shutterstock.

reasons they feel science needs a bigger voice in Washington. Sarah Vorpahl, senior energy policy specialist at Washington State Department of Commerce and a former Congressional Fellow in the office of Senator Bernie Sanders (I-Vt.), expressed similar sentiments saying, "The momentum for scientists stepping into politics was palpable following the 2016 election."

This momentum drove two key responses from the STEM community. First, millions of people across the United States (and across the globe) participated in the March for Science [covered in the August 2017 issue of MRS Bulletin]. This movement "provided a ready outlet for scientists and science supporters to have a collective voice and engage in the political process," says Ashley White, director of communications for the Advanced Light Source at Lawrence Berkeley National Laboratory and chair of the Materials Research Society (MRS) Congressional Science and Engineering Fellowship Program. The second important outcome was that hundreds of scientists and STEM professionals were galvanized to run for public office in 2018.

"Many scientists do research to make a difference in the world, such as through medical advancement or clean energy," Vorpahl says. "I think that those who have focused their careers and training on making the world a better place through technology saw an opportunity to have an impact in a different way ... science was in need of a defender and many in the nation took up the call." Megan Brewster, vice president for advanced manufacturing at Launch Forth and a former senior policy advisor at the White House Office of Science and Technology Policy, adds that she believes that scientists have realized "that today's grandest challenges require an all-hands-on-deck approach" and says she is "thrilled that scientists are 
Table I: STEM and Medical Professionals of the 116th Congress.

\begin{tabular}{|c|c|c|c|c|c|}
\hline Name & $\begin{array}{l}\text { Senate } \\
\text { or House }\end{array}$ & Party & State & Background & $\begin{array}{c}\text { Action } 314 \\
\text { Support }\end{array}$ \\
\hline Ralph Abraham & House & Republican & Louisiana & Medicine (Physician \& Veterinarian) & $\mathrm{N}$ \\
\hline Brian Babin & House & Republican & Texas & Medicine (Dentistry) & $\mathrm{N}$ \\
\hline John Barrasso & Senate & Republican & Wyoming & Medicine (Physician) & $\mathrm{N}$ \\
\hline Karen Bass & House & Democrat & California & Medicine (Registered Nurse) & $\mathrm{N}$ \\
\hline Ami Bera & House & Democrat & California & Medicine (Physician) & Y \\
\hline Eddie Bernice Johnson & House & Democrat & Texas & Medicine (Registered Nurse) & $\mathrm{N}$ \\
\hline Larry Bucshon & House & Republican & Indiana & Medicine (Physician) & $\mathrm{N}$ \\
\hline Michael Burgess & House & Republican & Texas & Medicine (Physician) & $\mathrm{N}$ \\
\hline Tony Cardenas & House & Democrat & California & Engineering (Electrical) & $\mathrm{N}$ \\
\hline Bill Cassidy & Senate & Republican & Louisiana & Medicine (Physician) & $\mathrm{N}$ \\
\hline Sean Casten* & House & Democrat & Illinois & Engineering (Biochemical) & Y \\
\hline Chris Collins & House & Republican & New York & Engineering (Mechanical) & $\mathrm{N}$ \\
\hline TJ Cox* & House & Democrat & California & Engineering (Chemical) & Y \\
\hline Joe Cunningham* & House & Democrat & South Carolina & Engineering (Ocean) & Y \\
\hline Steve Daines & Senate & Republican & Montana & Engineering (Chemical) & $\mathrm{N}$ \\
\hline Scott DesJarlais & House & Republican & Tennessee & Medicine (Physician) & $\mathrm{N}$ \\
\hline Neal Dunn & House & Republican & Florida & Medicine (Physician & $\mathrm{N}$ \\
\hline Bill Foster & House & Democrat & Illinois & Physics & Y \\
\hline Drew Ferguson & House & Republican & Georgia & Medicine (Dentistry) & $\mathrm{N}$ \\
\hline Paul Gosar & House & Republican & Arizona & Medicine (Dentistry) & N \\
\hline Andy Harris & House & Republican & Maryland & Medicine (Physician) & $\mathrm{N}$ \\
\hline Martin Heinrich & Senate & Democrat & New Mexico & Engineering (Mechanical) & Y \\
\hline Kevin Hern* & House & Republican & Oklahoma & Engineering (Aerospace) & $\mathrm{N}$ \\
\hline Chrissy Houlahan* & House & Democrat & Pennsylvania & Engineering (Industrial) & Y \\
\hline John Joyce* & House & Republican & Pennsylvania & Medicine (Physician) & N \\
\hline Joseph P. Kennedy III & House & Democrat & Massachusetts & Engineering (Management Science) & $\mathrm{N}$ \\
\hline Dan Lipinski & House & Democrat & Illinois & Engineering (Mechanical) & $\mathrm{N}$ \\
\hline Elaine Luria* & House & Democrat & Virginia & Engineering (Nuclear) & Y \\
\hline Roger Marshall & House & Republican & Kansas & Medicine (Physician) & $\mathrm{N}$ \\
\hline David McKinley & House & Republican & West Virginia & Engineering (Civil) & N \\
\hline Jerry McNerney & House & Democrat & California & Mathematics & Y \\
\hline John Moolenaar & House & Republican & Michigan & Chemistry & $\mathrm{N}$ \\
\hline Seth Moulton & House & Democrat & Massachusetts & Physics & Y \\
\hline Rand Paul & Senate & Republican & Kentucky & Medicine (Ophthalmology) & $\mathrm{N}$ \\
\hline Phil Roe & House & Republican & Tennessee & Medicine (Physician) & N \\
\hline Jacky Rosen ${ }^{\star \star}$ & Senate & Democrat & Nevada & $\begin{array}{l}\text { Computer Programmer } \\
\& \text { Software Developer }\end{array}$ & Y \\
\hline Raul Ruiz & House & Democrat & California & Medicine (Physician) & Y \\
\hline Brad Schneider & House & Democrat & Illinois & Engineering (Industrial) & $\mathrm{N}$ \\
\hline Kurt Schrader & House & Democrat & Oregon & Medicine (Veterinary) & $\mathrm{N}$ \\
\hline Kim Schrier* & House & Democrat & Washington & Medicine (Pediatrician) & Y \\
\hline Michael Simpson & House & Republican & Idaho & Medicine (Dentistry) & $\mathrm{N}$ \\
\hline Paul Tonko & House & Democrat & New York & Engineering (Mechanical \& Industrial) & Y \\
\hline Lauren Underwood* & House & Democrat & Illinois & Medicine (Registered Nurse) & Y \\
\hline Jeff Van Drew* & House & Democrat & New Jersey & Medicine (Dentistry) & Y \\
\hline Daniel Webster & House & Republican & Florida & Engineering (Electrical) & $\mathrm{N}$ \\
\hline Brad Wenstrup & House & Republican & Ohio & Medicine (Physician) & $\mathrm{N}$ \\
\hline Ted Yoho & House & Republican & Florida & Medicine (Veterinary) & $\mathrm{N}$ \\
\hline
\end{tabular}


leaning into the national dialogues about the importance and role of science."

In addition to the desire for better representation, access to resources likely played a role in the larger and more diverse candidate pool. Action 314 [also covered in the August 2017 issue of MRS Bulletin] supported scientists and medical professionals running for office by providing funds, training on how to run a successful campaign, and endorsements. Sixteen candidates, including eight newcomers, who were supported by Action 314 won their congressional elections (and many others won elections at the state and local levels) [see Table I].

"These new members can impact decision making from day one," White says, "but more importantly, if they remain in Congress and become more senior on key committees that oversee science policy and appropriations, we may start to see more significant changes in policies that impact the materials community, like those around climate change, energy, and STEM education." The budget process has a significant impact on what areas of science receive funding, and Hurd points out that "the non-diverse majority of the last two years has treated science and engineering quite well, standing off proposed cuts and even increasing some budgets for basic science." With the Congress now
split-Republicans control the Senate while Democrats control the House- - setting budgets will likely become more contentious, especially regarding issues that are divided on party lines like climate change.

The fact that the Democrats now control the House also means that committee leadership has changed and Vorpahl believes that "leadership will have a huge impact on how energy and environment issues are talked about at a federal level." Vorpahl illustrates her point saying, "The Science, Space and Technology Committee, which has been run by climate change deniers for almost a decade, is now chaired by Representative Eddie Bernice Johnson (D-Texas), a former chief psychiatric nurse. This marks the first time that the House science committee chair has a STEM background since the 1990s." And despite the fact that they are just learning the ropes, some of the newcomers are likely to significantly impact science- and materialsrelated issues. For example, Rep. Sean Casten (D-Ill.) is a likely champion for clean energy and environmental policy according to Arslan because he has "made clean energy his life work by founding a company that aims to reduce greenhouse-gas emissions by trapping and reusing energy from industrial facilities." And Vorpahl points out that Rep. Alexandria OcasioCortez (D-N.Y.) is already "endorsing aggressive, climate change movements that center around a 'Green New Deal' - a policy that sits at the nexus of environmental issues and income inequality and includes a call for $100 \%$ renewable energy and more jobs in clean energy."

While the increase in diversity and expertise within the 116th Congress will undoubtedly have an impact on a broad range of policy issues, perhaps even more importantly, "it will provide more diverse role models," White says. "Seeing more women, people of color, and scientists serving in Congress can build momentum and encourage even greater future diversity." Hurd echoes these sentiments, adding that the "most dramatic change in Congress is the influx of women," which he says in his experience will likely translate to better governance because "every group effort runs more smoothly with a healthy gender mix in leadership."

Brewster captures the importance of this moment in history saying, "The new Congress embodies a diversity of lived experiences - from those who have benefited from modern technologies, to those who have been displaced by new industries, to those who may take current technology advances for granted. We need this choir of voices to form robust legislative solutions for all of America."

Jennifer A. Nekuda Malik
Australia's GenCost 2018 finds renewables are cheapest new-build power www.csiro.au and www.aemo.com.au

$\mathrm{T}$ he Australian national science agency, CSIRO, and the Australian energy market operator, AEMO, have announced a new report on costs of electricity generation in the country.

The inaugural GenCost report, prepared collaboratively with a range of industry stakeholders, updates estimates of the cost to generate electricity from new power plants in Australia; GenCost 2018 found solar and wind technologies to be lowest cost.

CSIRO Chief Energy Economist and report lead author Paul Graham says GenCost 2018 was an essential annual benchmark to guide strategic decision making, given technology costs change significantly each year.

"Our data confirm that while existing fossil fuel power plants are competitive due to their sunk capital costs, solar and wind generation technologies are currently the lowest-cost ways to generate electricity for Australia, compared to any other new-build technology," Graham says.

The authors largely based their analysis on levelized cost of electricity, which includes operating as well as investment costs, and is the best way known to compare the costs of different technologies, like fossil fuel plants (which require relatively low capital costs, but higher operating expenses) and wind and solar (which require high capital outlays but low operating expenses).

"Data from GenCost 2018, combined with some of our previous research, indicate we may need additional flexible technologies - such as energy storage, demand management, and peaking gas plants - if the share of variable renewables increases beyond 50 percent," Graham says.

Research in 2019 will identify in more detail the least cost set of balancing solutions required by variable renewables once they represent a significantly larger share of the generation portfolio. 